\title{
PENGARUH KEMAMPUAN DAN MOTIVASI KERJA TERHADAP KINERJA KARYAWAN BAGIAN PRODUKSI PT. SENTOSA HASTAREKSA
}

\author{
Whidya Udaya Sari \\ Universitas Pendidikan Indonesia \\ whidyaudayasari@student.upi.edu \\ Hj. Sumiyati \\ Universitas Pendidikan Indonesia \\ sumiyati@upi.edu \\ Drs. H. Rd. Dian Herdiana Utama \\ Universitas Pendidikan Indonesia \\ Dhutama@upi.edu
}

\begin{abstract}
ABSTRAK
Persaingan dunia usaha yang semakin kompetitif, menuntut perusahaan untuk memiliki kinerja yang tinggi. Peningkatan kinerja sumber daya manusia (SDM) merupakan hal yang sangat penting dalam memperbaiki keberhasilan perusahaan, sehingga perlu diupayakan secara terus menerus dan berkesinambungan dalam menghadapi dunia global terutama pada industri ekspor impor di Indonesia. Kemampuan dan motivasi kerja dijadikan suatu cara untuk meningkatkan kinerja karyawan di bagian produksi PT. Sentosa Hastareksa. Penelitian ini bertujuan untuk mengetahui gambaran kemampuan, motivasi kerja terhadap kinerja karyawan, serta pengaruh kemampuan dan motivasi kerja terhadap kinerja karyawan bagian produksi PT. Sentosa Hastareksa. Objek penelitian ini adalah karyawan produksi PT. Sentosa Hastareksa. Variabel bebas dalam penelitian ini adalah kemampuan dan motivasi kerja, serta variabel terikat yaitu kinerja karyawan dengan jenis penelitian yang digunakan adalah deskriptif, verifikatif, dan metode yang digunakan adalah explanatory survey dengan teknik sampel simple random sampling dengan jumlah sampel 141 responden. Teknik analisa data yang digunakan adalah regresi liniear berganda dengan alat bantu software komputer SPSS 22.0 for windows. Hasil yang diperoleh dalam penelitian menyatakan bahwa kemampuan dan motivasi kerja berpengaruh terhadap kinerja karyawan. Dengan tingkat pengaruh kemampuan dan motivasi kerja terhadap kinerja karyawan kuat. Dari hasil penelitian terhadap pengujian hipotesis dapat diketahui bahwa kemampuan dan motivasi kerja memiliki pengaruh yang positif terhadap kinerja karyawan
\end{abstract}

Kata Kunci: Kemampuan, Motivasi Kerja, Kinerja Karyawan.

\section{PENDAHULUAN}

Rendahnya perkembangan sumber daya manusia di Indonesia menunjukkan masih banyak sumber daya manusia yang kurang berkualitas, sehingga kinerja sumber daya manusia di Indonesia relatif rendah. Keberhasilan suatu perusahaan sangat dipengaruhi oleh kinerja karyawannya, oleh karena itu setiap perusahaan akan selalu berusaha untuk meningkatkan kinerja karyawan agar tujuan perusahaan dapat tercapai secara maksimal. Salah satu kunci kerberhasilan suatu perusahaan adalah bagaimana membuat karyawan memiliki kemampuan (ability) dalam bidangnya dan menimbulkan rasa motivasi yang tinggi sehingga dapat meningkatkan kinerja pada karyawannya. Kinerja dikaitkan dengan konsep kemampuan karena untuk perbaikan dalam meningkatkan kualitas yang terbaik. Kemampuan tersebut merupakan kapasitas seseorang didalam mengerjakan berbagai macam tugas dalam pekerjaannya (Schermerhorn, Hunt dan Osborn 2011:391).

Hal ini senada dengan Harsh Pathak (2010:330) yang menyatakan bahwa faktor yang mempengaruhi kinerja adalah faktor kemampuan (ability) dan faktor motivasi (motivation).

Human Performance $=$ Ability $x$ motivation

Motivation = Attitude $x$ Situation

Ability $=$ Knowladge $x$ Skill

Penjelasan dari faktor kemampuan (Ability) adalah terdiri dari kemampuan potensi (IQ) dan kemampuan reality (Knowladge + skill). Artinya dengan pendidikan yang memadai untuk jabatan karyawan dan terampil dalam mengerjakan pekerjaan sehari-hari, maka akan lebih mudah mencapai kinerja yang maksimal. Sedangkan penjelasan faktor motivasi (motivation) diartikan suatu sikap (attitude) pimpinan dan karyawan terhadap situasi kerja (situation) dilingkungan organisasinya. Mereka yang bersikap pro terhadap 
situasi kerjanya akan menunjukan motivasi tinggi dan sebaliknya jika mereka bersikap kontra terhadap situasi kerjanya akan menunjukan motivasi kerja rendah. Dijelaskan situasi kerja menurut Mangkunegara (2012:331) adalah mencakup antara lain hubungan kerja, fasilitas kerja, iklim kerja, kebijakan pemimpin, pola kepemimpinan kerja dan kondisi kerja.

Menurut Gomez-Mejia, Balkin dan Cardy (2012:225) yang mengidentifikasi dimensi kinerja terdiri dari :

1. Quality of Work, yaitu kualitas kerja yang dicapai berdasatkan syarat-syarat kesesuaian dan kesiapannya

2. Quantity of Work Performed,yaitu jumlah kerja yang dilakukan dalam suatu periode waktu yang ditentukan

3. Interpersonal effectiveness, yaitu menyangkut kepribadian, kepemimpinan, dan integritas pribadi

4. Competencies, yaitu luasnya pengetahuan mengenai pekerjaan dan keterampilannya

5. Job Knowladge, yaitu luasnya pengetahuan mengenai pekerjaan dan keterampilannya.

Rendahnya kinerja akan berpengaruh terhadap perusahaan, hal ini mengakibatkan pencapaian tujuan perusahaan tidak maksimal. Bahkan pengaruhnya dapat menghambat proses ekspor impor di Indonesia. Fenomena pada masalah penurunan kinerja tersebut dialami oleh karyawan pada beberapa perusahaan di Indonesia salah satunya pada PT Sentosa Hastareksa yang mengekspor kayu olahan kuas.

Hal tersebut dapat dilihat pada data hasil penilaian kinerja di PT Sentosa Hastareksa pada tahun 2010 hingga 2014 terdapat beberapa indikator yang mengalami peningkatan setiap tahunnya, namun masih ada beberapa indikator yang mengalami penurunan. Pencapaian sasaran yang ditetapkan perusahaan untuk jumlah penilaian seluruh indikator adalah $100 \%$. Dengan demikian data diatas menunjukan masih belum optimalnya kinerja karyawan. Masalah yang dialami PT Sentosa Hastareksa adalah penurunan kinerja karyawan yang disebabkan oleh kurang maksimalnya kemampuan dan motivasi pada karyawan PT Sentosa Hastareksa sehingga membuat hasil kinerja dan produksi terus menurun sehingga hasil produksi yang dihasilkan tidak sesuai dengan target yang ditetapkan oleh perusahaan.

Oleh karena itu peneliti mengambil judul

Pengaruh Kemampuan dan Motivasi Kerja Terhadap Kinerja Karyawan.

\section{METODE PENELITIAN}

Unit analisis yang dijadikan responden dalam penelitian ini adalah karyawan produksi PT. Sentosa Hastareksa. Oleh karena itu akan diteliti pengaruh kemampuan dan motivasi kerja terhadap kinerja karyawan bagian produksi PT. Sentosa Hastareksa. Penelitian ini dilakukan dalam kurun waktu kurang dari satu tahun, maka metode yang digunakan adalah cross sectional method, pengumpulan informasi dari subjek penelitian hanya dilakukan satu kali dalam satu periode waktu, sehingga penelitian ini merupakan cross sectional. Penelitian ini dilakukan pada bulan Juli hingga November 2015. Populasi dalam penelitian ini adalah karyawan produksi PT. Sentosa Hastareksa pada tahun 2015 sebanyak N: 246 anggota. Pengambilan sampling menggunakan simple random sampling dari jumlah populasi dan dengan menggunakan rumus Slovin diperoleh sampel sebanyak 141 responden

\section{HASIL PENELITIAN DAN PEMBAHASAN}

Hasil pengujian antar variabel kemampuan $\mathrm{X}_{1}$ dan $\mathrm{X}_{2}$ terhadap $\mathrm{Y}$ secara keseluruhan memberikan hasil yang signifikan. Maka untuk mengetahui antara variabel $\mathrm{X}_{1}$ kemampuan dan variabel $\mathrm{X}_{2}$ motivasi kerja terhadap variabel kinerja karyawan (Y) dapat dilanjutkan dengan pengujian secara parsial.

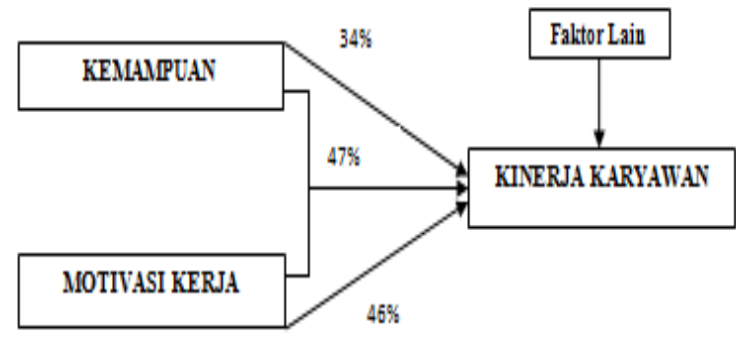

GAMBAR 1

PENGARUH KEMAMPUAN DAN MOTIVASI KERJA TERHADAP KINERJA KARYAWAN

Berdasarkan Gambar 1 menunjukkan koefisien jalur antara kemampuan dan motivasi kerja dimana besar koefisien kemampuan memberikan pengaruh kurang signifikan terhadap kinerja karyawan.

Berdasarkan hasil penelitian yang dilakukan oleh Dobre (2013) ada beberapa faktor yang mempengaruhi kinerja karyawan antara lain, motivation, appraisals,ability, job satisfaction, training and development. Menurut penelitian terdahulunya Victoria Büsch, Dennis Dittrich, Uta Lieberum (2010) menunjukkan bahwa, terdapat dampak positif yang signifikan pada kemampuan terhadap kinerja karyawan.

Selain kemampuan terdapat faktor lain yang mempengaruhi kinerja yaitu motivasi kerja. Didukung dengan penelitian terdahulu yang dilakukan oleh Shehzad and Zameer (2014) menjelaskan bahwa tanpa memotivasi karyawan suatu perusahaan tidak akan dapat mencapai tujuannya karena motivasi karyawan dan 
kemampuan mereka secara kolektif berpartisipasi dalam kinerja karyawan dan tugas yang sulit yang diberikan oleh manajer adalah memperoleh hasil yang maksimal, baik motivasi yang berasal dari dalam diri karyawan itu sendiri ataupun motivasi yang berasal dari luar, karena motivasi menjadi pendorong seseorang melaksanakan suatu kegiatan guna mendapat hasil yang terbaik (Manmohan Joshi, 2013:55). Oleh karena itu tidak heran jika karyawan yang mempunyai motivasi kerja yang tinggi biasanya memiliki kinerja yang tinggi. Untuk itu motivasi kerja karyawan perlu dibangkitkan agar karyawan dapat menghasilkan kinerja yang terbaik, semakin tinggi motivasi karyawan dalam bekerja maka kinerja yang dihasilkan pun tinggi.

Hal ini menunjukkan bahwa jika semakin baik perusahaan membangun program kemampuan dan motivasi kerja kepada karyawan produksi maka akan semakin baik juga kinerja karyawan yang dihasilkan pada PT. Sentosa Hastareksa.

\section{KESIMPULAN DAN REKOMENDASI}

\section{Kesimpulan}

Variabel kemampuan dan motivasi kerja memiliki pengaruh yang positif dan signifikan terhadap kinerja karyawan dengan pengaruh yang cukup tinggi dari kedua variabel tersebut untuk mempengaruhi kinerja karyawan dalam menghasilkan output yang maksimal. Hal ini menunjukkan bahwa semakin baik perusahaan membangun program kemampuan dan motivasi kerja maka akan semakin baik juga kinerja karyawan yang dihasilkan pada PT. Sentosa Hastareksa.

\section{Rekomendasi}

Hasil penelitian menyatakan kemampuan dan motivasi kerja berpengaruh secara positif dalam meningkatkan kinerja karyawan maka penulis merekomendasikan agar PT. Sentosa Hastareksa lebih meningkat kinerja karyawan dengan cara meningkatkan knowledge: pendidikan, pengalaman, pelatihan, minat, dan skill: bakat, kepribadian. Terutama pada keterampilan yang dimiliki karyawan. Hal tersebut agar perusahaan dapat mempertahankan sumber daya manusia yang unggul demi perkembangan dan tujuan perusahaannya.

Selain itu perusahan harus memperbaiki atau meningkatkan motivasi kerja yang tinggi akan tanggung jawab, berjuang untuk mempengaruhi individu lain, dan senang ditempatkan dalam situasi yang kompetetif dan berorientasi status, serta cenderung lebih khawatir dengan wibawa dan mendapatkan pengaruh atas individu daripada kinerja yang efektif.

\section{DAFTAR PUSTAKA}

Dobre Ovidiu Iluita. 2013. "Employee Motivation and Organizational Performance”. Vol. 5 Iss 1, pp. 53. Review of Applied Socio-Economic Research 2247-6172

Harsh, Pathak. 2010. Organizational Change. New Delhi: Harper Collins India. Pearson Education

Joshi, Manmohan. 2013. Human Resources Management Edition $1^{\text {th }}$. Venns Publishing Denmark

Mangkunegara, A.A. Anwar Prabu. 2012. Evaluasi Kinerja SDM. Bandung : PT. Refika Aditama

Mejia, Gomez., Luis R and David B. Balkin and Robert L. Cardy. 2012. Managing Human Resources.. New Jersey: Pearson Education

Schermerhorn, J.R, Hunt, J.G., \&Osborn, R.N. 2011. Managing Organizational Behaviour. New York: John Willey \& Son

Victoria Büsch, et al. 2010. "Determinants of Work Motivation and Work Ability among Older Workers and Implications for the Desire for Continued Emplymnent". Comparative Population Studies - Zeitschrift für Bevölkerungswissenschaft. Vol. 35, No. 4

Zameer, Hasim., Shehzad Ali. 2014. "The Impact of the Motivation on the Employee's Performance in Beverage Industry of Pakistan". International Journal of Academic Research in Accounting, Finance and Management Sciences. Vol. 4, No. 1, pp. 293-298. CHRMARS [ISSN 2225-8329] 